\title{
Research on Classification Reform of Chinese State-Owned Enterprises
}

\author{
Xu Lin ${ }^{1}$, Zhang Guoyi ${ }^{1}$, Yuan Wei ${ }^{1} \&$ Jiang Yuan ${ }^{2}$ \\ ${ }^{1}$ Sichuan Institute of Administration, China \\ ${ }^{2}$ School of Economics, Peking University, China \\ Correspondence: Yuan Wei, Sichuan Institute of Administration, China. E-mail: yuanwei_sc@163.com
}

Received: February 25, 2019

Accepted: March 28, 2019

Online Published: April 18, 2019

doi:10.5539/ijbm.v14n5p106

URL: https://doi.org/10.5539/ijbm.v14n5p106

\begin{abstract}
The classification reform of state-owned enterprises is a major movement in the process of the new round of reform of state-owned enterprises in China. This paper will focus on the implementation of the classification reform of state-owned enterprises, and conduct research and analysis on the implementation path, current situation and difficulties of the classification reform of state-owned enterprises. The first part of the implementation path is divided into three levels: the transfer of capital to the management of the property level, the formation of a differentiated governance structure combining internal and external governance, and the clarification of the authority of state-owned assets. The implementation logic of the three levels is elaborated. The second part of the local provinces' relevant initiatives were introduced from the functional positioning and classification, the implementation of supervision and the implementation of the mixed ownership reform. The third part focuses on the key points and difficulties of the reform of state-owned enterprises. It mainly studies the practical issues of "diversified and multi-functional" classification reform of state-owned enterprises and regulatory conflicts, "rights" and "human rights". The fourth part promotes the policy recommendations for the effective implementation of the classification reform of state-owned enterprises.
\end{abstract}

Keywords: state-owned enterprise, property, classification reform

\section{Introduction}

Give full play to the decisive role of the market in the allocation of resources in the Chinese economic system. It is not only necessary to rationalize the institutional design of the Chinese central government and local governments to protect the effectiveness of market mechanisms such as price, competition, and information, but also to cultivate clear property rights from the micro level. Market micro-subjects with contractual spirit and good profitability.

State-owned enterprises of China have made great contributions to the healthy development of the national economy for a long time. However, many problems such as unclear property rights in the development of state-owned enterprises, lack of incentives for business operations, low operating performance, and loss of state-owned assets cannot be properly resolved, which will inevitably have a negative impact on the sound and perfection of China's socialist market economy. In order to build a state-owned enterprise that is suitable for the development of the market economy, and accelerate the reform of state-owned enterprises to achieve quality and efficiency, the "Guiding Opinions on Deepening the Reform of State-Owned Enterprises" issued by the Central Committee of the Communist Party of China and the State Council in August 2015 is the general framework for the new round of reform of Chinese state-owned enterprises. It divides state-owned enterprises into two categories: commercial and public welfare. Through this function definition and classification method, it implements "classification reform, classification development, classification supervision, classification and responsibility, and classification assessment" for state-owned enterprises. In order to promote the more accurate and effective implementation of the classification reform of state-owned enterprises, the relevant ministries and commissions has issued two policies to guide the implementation of the reform of state-owned enterprises. In order to clarify the basic ideas of SOE classification reform, in December 2015, the SASAC, the Ministry of Finance, and the National Development and Reform Commission jointly issued the "Guiding Opinions on the Definition and Classification of State-Owned Enterprises". The standard is explained. According to the relevant explanations in the "Guiding Opinions on the Definition and Classification of State-Owned Enterprises", 
commercial and public-sector state-owned enterprises have major differences in their main business objectives, reform ideas and reform goals.

Table 1. The difference between the classification reform of business and public welfare state-owned enterprises

\begin{tabular}{|c|c|c|c|}
\hline $\begin{array}{l}\text { Type of } \\
\text { state-owned } \\
\text { enterprise }\end{array}$ & $\begin{array}{ll}\text { Main } & \text { business } \\
\text { objectives } & \end{array}$ & Reform ideas & Reform purpose \\
\hline $\begin{array}{l}\text { Business } \\
\text { state-owned } \\
\text { enterprises }\end{array}$ & $\begin{array}{l}\text { Enhance the vitality } \\
\text { of the state-owned } \\
\text { economy. } \\
\text { Enlarge the function } \\
\text { of state-owned } \\
\text { capital. } \\
\text { To realize the } \\
\text { preservation and } \\
\text { appreciation of } \\
\text { state-owned assets. }\end{array}$ & $\begin{array}{l}\text { In accordance with the requirements of marketization, } \\
\text { the company will implement commercial operations, } \\
\text { independently carry out production and business } \\
\text { activities in accordance with the law, and achieve the } \\
\text { survival of the fittest and orderly advancement and } \\
\text { retreat. }\end{array}$ & $\begin{array}{l}\text { Focus on the development of } \\
\text { forward-looking strategic industries } \\
\text { to achieve an organic unity of } \\
\text { economic, social and safety } \\
\text { benefits. }\end{array}$ \\
\hline $\begin{array}{l}\text { Public welfare } \\
\text { state-owned } \\
\text { enterprises }\end{array}$ & $\begin{array}{l}\text { Protect people's } \\
\text { livelihood. } \\
\text { Serve the society. } \\
\text { By providing public } \\
\text { goods and services. }\end{array}$ & $\begin{array}{l}\text { The price of the necessary products or services can be } \\
\text { regulated by the government and the market mechanism } \\
\text { must be actively introduced. }\end{array}$ & $\begin{array}{l}\text { Continuously improve the } \\
\text { efficiency and capabilities of public } \\
\text { services. }\end{array}$ \\
\hline
\end{tabular}

In order to further strengthen the classification and assessment of central enterprises, in August 2016, the State-owned Assets Supervision and Administration Commission and the Ministry of Finance issued the "Implementation Plan for Improving the Functional Classification Assessment of Central Enterprises". In the "Proposal", the assessment types of central enterprises were reorganized into three categories, and The corresponding assessment criteria, the main business is in the fully competitive indlustry and the field of business-oriented central enterprises should highlight the return on capital and economic efficiency indicators (commercial class I central enterprises); the main industry relations national security, the national economy lifeline important industries and key areas of business The central enterprises should take into account the social benefit indicators and economic efficiency indicators. For the economic efficiency assessment indicators and the social benefit indicators involving national security and national major special tasks, they should be given reasonable weight according to the actual situation (commercial class II central enterprises); public welfare central enterprises should focus on Evaluate social benefit indicators such as product service quality, cost control, operational efficiency and support capabilities. The SASAC's implementation of the functional assessment of central enterprises is mainly based on the market power of the enterprise and the product and service attributes of the production. The following chart can be used to illustrate the classification. The horizontal axis shows the monopoly power of the central enterprises, and the vertical axis shows the types of products provided.

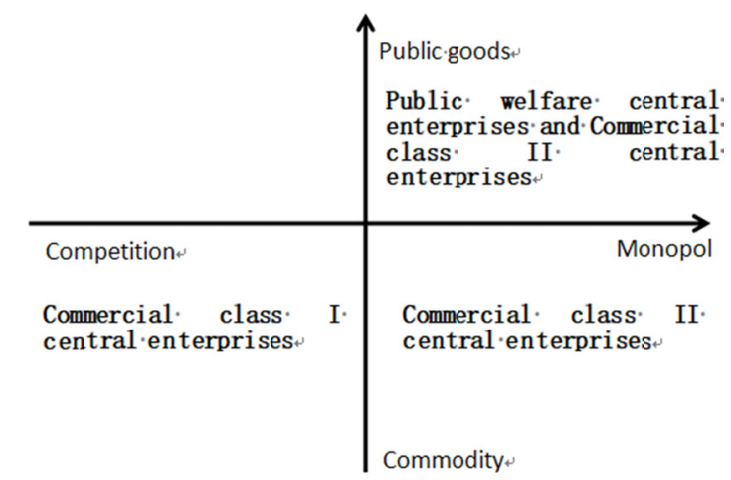

Figure 1. Three types of central enterprises classification 


\section{The Implementation Path of the Classification Reform of State-Owned Enterprises}

The current state-owned enterprise classification reform is the starting point of a new round of state-owned enterprise reform. The purpose is to smooth out the relationship between state-owned enterprises and markets as government agents, and to accurately locate different types and functions of state-owned enterprises. The previous reform of state-owned enterprises was based on the assumption that the state-owned enterprises had inefficient property rights and established market entities with clear property rights. Putting the focus of reform on the property rights of state-owned enterprises could not solve the problem of indiscriminate government and enterprises and difficult to trade property rights (Note 1). At this stage, the classification reform of state-owned enterprises determines the classification criteria of different types of state-owned enterprises, and implements the diversity and comprehensive reform of property rights level and internal governance according to their products, industries and functional characteristics.
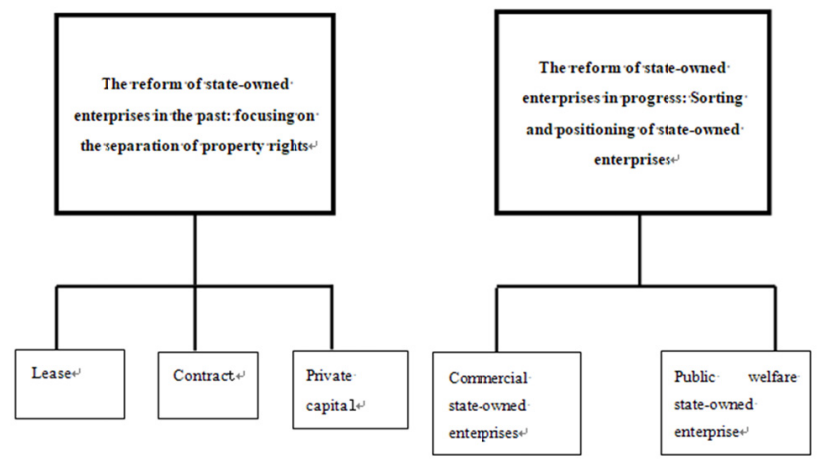

Figure 2. Comparison of the logical ideas of the reform of new and old state-owned enterprises

The implementation path of the classification reform of state-owned enterprises is a systematic project, and the ultimate goal is to achieve the dual improvement of economic and social benefits of state-owned enterprises. The specific implementation path involves three levels of reform, and these three levels of reforms show a progressive relationship.

\subsection{State-Owned Enterprise Classification Reform and Mixed Ownership Reform: Changing To Managed Capital}

The offside, absent, and misplaced problems in the supervision and management of state-owned assets in China are an important factor leading to the loss of state-owned assets and inefficient production capacity. The "back-end" management model is the main cause of problems caused by management products and enterprise assets. As a result, the efficiency of capital use in the process of capital, capital and ultimately the formation of assets cannot be optimized, and the scope and function of state-owned capital are suppressed. In order to improve the efficiency of state-owned capital and enhance the influence of the state-owned economy and the ability to resist risks, in April 2017, the State-owned Assets Supervision and Administration Commission of the State Council issued the "Sino-SASAC-based Capital Management Promotion Program", emphasizing the need to be based on national strategic objectives and state-owned capital. The structural layout and the central enterprise's main business adopt market-oriented operation methods and differentiated assessments to improve capital efficiency.

The reform of state-owned enterprises classification is the cornerstone of the reform of mixed ownership reform and the reform of state-owned assets supervision system. According to the three types of state-owned enterprises divided by the State-owned Assets Supervision and Administration Commission, the reform of mixed ownership will be promoted. Among them, commercial I-type state-owned enterprises are active in the industry, and their mixed reforms aim to increase the industrial competitiveness and return on capital of state-owned capital. Leading to external investors, the choice of equity investment will be more diversified, and it can be absolutely controlled, relatively controlled or shareholding enterprises; commercial class II state-owned enterprises are in key industries and fields involving national security and national economic lifeline, and must guarantee state-owned capital in mixed reform. Control, we must strengthen the ability of state-owned capital to integrate with the industry. In the company's shareholding, we must guarantee absolute control and relative control with strong control. External investors can participate in shares. Public welfare state-owned enterprises generally 
require state-owned capital to be wholly-owned and wholly-owned. Or absolute holding, qualified to promote equity diversification, such as PPP mode, in order to improve the quality and quantity of public goods and public services, you can adopt the BOT, TOT or BT model, and ultimately achieve the fundamental purpose of improving the efficiency of the use of state-owned capital.

\subsection{Differentiated Governance Structure: The Pursuit of Internal and External Governance}

The new round of state-owned enterprise reform and the previous goal of state-owned enterprise reform are all aimed at improving the management and management capabilities of state-owned enterprises and ensuring the preservation and appreciation of state-owned assets. The way to achieve it is to form a reasonable governance structure.

In the past, the reform of state-owned enterprises regarded state-owned enterprises as the mainstay of the market, and improved the internal management environment of state-owned enterprises with the modern enterprise governance system of "three sessions". The failure of the supervision and management function of the state-owned assets supervision department has led to problems between the government and enterprises. The actual control rights are in the hands of state-owned enterprise executives, and the internal controllers are more serious, which leads to reform inefficiency.

The reform of state-owned enterprises will no longer regard state-owned enterprises as the main players of the general market. According to different types of state-owned enterprises, they will design a governance structure that is in line with the internal and external conditions of state-owned enterprises. First of all, commercial I-type state-owned enterprises should be based on the internal management of modern enterprises in the "three-one-one level" due to the high degree of marketization of the industry sectors and products, and give full play to the role of state-owned capital in the board of directors and managers. Improve corporate business performance and maximize the return on state-owned capital as an internal governance goal. Secondly, the commercial class II state-owned enterprises are more complicated. They not only have the market-oriented components for realizing economic benefits, but also take into account national security and national economic strategies. Such enterprises should adopt a "inside-outside" governance structure, and build a board of directors to the management and internal supervisory committees. A normalized internal governance structure for the board of directors. Third, public welfare state-owned enterprises mainly play the role of external supervision to ensure the direction of the main business and the quantity and quality of products supplied. In addition, the external director system is critical to all three types of state-owned enterprises.

\subsection{List of Powers and Responsibilities for Supervision of State-Owned Assets Supervision: Clarifying the} Authority of State-Owned Assets

In order to solve the problems of the offside, absence, misplacement and other problems in the supervision process of the state-owned assets supervision department, the regulatory functions are correctly positioned. In 2015, the "Guiding Opinions on Deepening the Reform of State-Owned Enterprises" issued by the Central Committee of the Communist Party of China and the State Council clearly stated that "the transformation of the functions of state-owned assets supervision institutions should be promoted by tube capital", which marked that the state-owned assets supervision institutions were mainly "management enterprises". The shift to "management capital" and the decentralization of management will further reduce the administrative intervention for the operation of state-owned enterprises. The state-owned assets supervision department will pay more attention to the performance of state-owned enterprises in the future.

Clearing the regulatory boundaries and clarifying the authority are the key to improving the quality of state-owned assets supervision. According to the regulatory thinking of "tube capital", the capital supervision of state-owned enterprises should be divided into three levels. The first level is the management of capital structure. The regulation of capital structure of commercial I-type state-owned enterprises is more flexible and flexible. It can be absolutely controlled, relatively controlled or shareholding, and the capital structure is designed to achieve the return of market capital. The commercial category II state-owned enterprises are satisfied. National strategy needs to ensure that state-owned capital has a large proportion of capital structure in controlling capital. The second level is the allocation of capital. The commercial I type of SOEs has a wider range of capital allocation and relatively loose regulation. On the basis of pursuing capital returns, the market-based approach to the survival of the fittest is based on specific industries, industrial developments and profitability. Configuration. Commercial Class II SOEs are more likely to maintain their main business direction in the process of capital allocation, and they can make capital investments in upstream and downstream or peripheral industries with profitable main businesses to obtain income. Public welfare state-owned enterprises mainly invest in the public sector, and there are restrictions on investment-profit industries. The third level is the management of capital 
performance. For the capital performance appraisal of commercial class I state-owned enterprises, financial indicators such as return on capital and EVA can be mainly considered to highlight its marketization and profitability. The performance appraisal of commercial class II state-owned enterprises is more complicated, which involves not only the financial indicators of commercial class I state-owned enterprises, but also the social effect indicators generated into the performance appraisal indicator system.

\section{The Implementation Status of the Reform of State-Owned Enterprises in Local Provinces}

Since the Central Committee of the Communist Party of China and the State Council issued the "Guiding Opinions on Deepening the Reform of State-Owned Enterprises" in August 2015, all provinces have introduced corresponding policies to promote the reform of state-owned enterprises.

\subsection{Classification and Functional Positioning of Local Soes in Some Provinces}

As an economically developed capital and municipality directly under the Central Government, Beijing and Shanghai have always maintained the characteristics of the system first. As early as August 2014, Beijing issued the "Opinions on Comprehensively Deepening the Reform of State-owned Enterprises in State-owned Enterprises". In the "Opinions", the state-owned enterprises in the city were divided into three categories: urban public services, special functions, and competition. In July 2014, the Shanghai Municipal Government issued the "Several Opinions on Promoting the State-owned Enterprises in the City to Actively Develop a Mixed Ownership Economy (Trial)", which divided the state-owned enterprises into three types: competition, function and public service. However, the functions of the three types of state-owned enterprises have not been elaborated.

Beginning in 2016, other provinces actively carried out local practice in accordance with the "Guiding Opinions on Deepening the Reform of State-Owned Enterprises" of the Central Committee of the Communist Party of China and the State Council and the "Guiding Opinions on the Definition and Classification of State-Owned Enterprises" by the State-owned Assets Supervision and Administration Commission, the Ministry of Finance, and the National Development and Reform Commission. Some provinces are classified according to the principle of "three-point method" and some provinces have made a more subdivided division according to the actual situation of the region. Some of the provinces have classified and published a list of specific state-owned enterprises. For example, in April 2016, the "Notice on Declaring the Function Definition and Classification of Provincial Capital-funded Enterprises" issued by the State-owned Assets Supervision and Administration Commission of Hubei Province divided the provincial state-owned enterprises into fully competitive commercial state-owned enterprises, undertaking major special tasks, commercial state-owned enterprises and special-function state-owned enterprises. The three categories define their functions separately.

Table 2. Classification of 19 state-owned enterprises in Hubei Province

\begin{tabular}{|c|c|c|}
\hline Classifications & Name & Amount \\
\hline Full competition & $\begin{array}{l}\text { Sanhuan Group Co., Ltd, Hubei } \\
\text { Changjiang Industrial Investment Group } \\
\text { Co., Ltd., } \\
\text { Hubei High-tech Industrial Investment } \\
\text { Co., Ltd., Zhongnan Engineering } \\
\text { Consulting Design Group Co., Ltd. }\end{array}$ & 10 \\
\hline & Hubei Provincial Transportation & \\
\hline Undertake major special tasks business & $\begin{array}{l}\text { Investment Group Co., Ltd., } \\
\text { Hubei Railway Construction Investment } \\
\text { Group Co., Ltd., } \\
\text { Hubei Airport Group Co., Ltd. }\end{array}$ & 6 \\
\hline Special function & $\begin{array}{l}\text { Hubei Chuyi Group Co., Ltd., } \\
\text { Hubei Dingan Group Co., Ltd. }\end{array}$ & 2 \\
\hline
\end{tabular}

In June 2016, the "Guiding Opinions on the Definition and Classification Supervision of Provincial Enterprises" (Trial) issued by the State-owned Assets Supervision and Administration Commission of Sichuan Province identified provincial state-owned enterprises as commercial state-owned enterprises, mainly functional state-owned enterprises and competitive state-owned enterprises, and further refined. It is divided into four types: functional type I, functional type II, competitive type I, and competition type II. In addition, Chongqing, 
Shandong, Henan, Zhejiang and other provinces have also introduced the corresponding provincial SOE function definition and classification schemes and published a list of provincial SOE functional divisions, from the local practice of SOE classification reform, although it is divided according to local conditions. The methods and types are slightly different, but the direction of reform is generally the same.

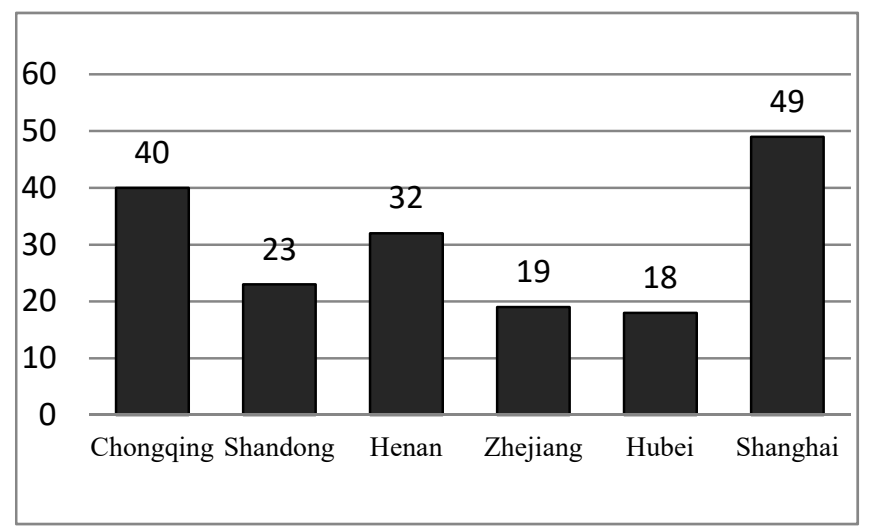

Figure 3. Number of state-owned enterprises reformed by classification in some provinces

\subsection{Implementation of classification supervision in some provinces}

Accurate functional positioning and classification is the cornerstone of SOE classification reform, and effective and rational classification and supervision system is a powerful guarantee for the implementation of SOE classification reform. The design and system construction of classification supervision system in some provinces shows strong practical application. . In May 2015, the State-owned Assets Supervision and Administration Commission of Heilongjiang Province, a large state-owned enterprise, issued the "Implementation Opinions on the Classified Supervision of the Provincial-owned Assets Supervision and Administration Commission". The "Opinions" established the shareholding structure, corporate governance, selection and employment, layout adjustment, and compensation management. The performance appraisal, the supervision of the Board of Supervisors and the state-owned capital operation budget cover eight aspects of the supervision system, and each aspect stipulates the corresponding implementation rules for the three types of state-owned enterprises, namely, commercial class, commercial class II and public welfare class, such as corporate governance. To stipulate commercial enterprises, we should establish and improve the corporate governance structure of the "three-level one-level".

To achieve differentiated supervision based on the rational classification of state-owned enterprises, it is necessary not only to clarify the specific aspects of supervision, but also to construct a government classification assessment system that is in line with local conditions. In 2016, the "Implementation Opinions on Strengthening and Improving the Supervision of State-Owned Assets of Enterprises" issued by the People's Government of Henan Province proposed to "improve the assessment system and methods, comprehensively assess the quality, efficiency and profit of capital operations, with economic value added as the mainstay, and Incorporate transformation and upgrading, innovation-driven, compliance management, and fulfilling social responsibilities into the assessment index system, and differentiate the distribution methods according to different functions and types of enterprises.

\subsection{Promotion of Mixed Ownership Reform in Some Provinces}

The reform of state-owned enterprise ownership is the necessary means to stimulate property rights to improve property rights performance. It is the focus of a new round of state-owned enterprise reform. Accurate property rights relations and capital structure adjustment are the difficulties in the process of promoting mixed ownership reform in various provinces. Some provinces implement mixed state-owned enterprise reform. Use "classification advancement" as a catcher.

In 2017, the "Implementation Opinions on the Development of a Mixed Ownership Economy for State-Owned Enterprises" issued by the Hunan Provincial People's Government will be a key subject of mixed reform of commercial enterprises, and conditional public enterprises can also implement mixed reforms. In the "Implementation Opinions", three different implementation plans are divided by the nature of the state in which the state-owned enterprises are located. They are in the important industries and key areas that are related to national security and the lifeline of the national economy, and mainly undertake commercial tasks (including 
functional categories and competitions). Class) State-owned enterprises must maintain state-owned capital holding position and support non-state-owned capital participation.

In 2015, the People's Government of Hebei Province issued the "Implementation Opinions on the Development of Mixed Ownership Economy by Local State-Owned Enterprises", which mainly carried out mixed reforms of commercial state-owned enterprises. Among them, state-owned enterprises in the field of full competition should actively realize the introduction of other state-owned capital and non-state-owned capital to realize equity. Diversification. Commercial SOEs that undertake provincial and municipal strategies and major special tasks must maintain state-owned capital holdings and support non-state-owned capital participation.

Table 3. Hebei Province undertakes special implementation tasks for commercial enterprises

\begin{tabular}{ll}
\hline Scopes & Mixed rules \\
\hline $\begin{array}{l}\text { Important hub-type transportation infrastructure, controlled } \\
\text { water conservancy and hydropower projects in river basins, },\end{array}$ & $\begin{array}{l}\text { Implement state-owned or controlled state, and allow qualified } \\
\text { non-state-owned enterprises to participate in construction and } \\
\text { operation in accordance with the law through franchising and } \\
\text { and inter-basin water transfer projects. }\end{array}$ \\
$\begin{array}{ll}\text { Development and utilization of important water resources, } \\
\text { Implement state-owned or absolute holdings, and allow } \\
\text { coastline resources, forest resources, and strategic mineral } \\
\text { nesources. }\end{array}$ & $\begin{array}{l}\text { non-state-owned capital to enter on the basis of strengthening } \\
\text { environmental, quality, and safety supervision, and participate } \\
\text { in development and management in accordance with the law. }\end{array}$ \\
$\begin{array}{ll}\text { In addition to the state-owned or absolute control of the pipe } \\
\text { nuch as river main channel and oil and gas. }\end{array}$ & $\begin{array}{l}\text { network of the natural monopoly, the company will let go of } \\
\text { competitive business and allow non-state capital to enter on an }\end{array}$ \\
& $\begin{array}{l}\text { equal footing. } \\
\text { Implement state-owned or absolute holdings to support } \\
\text { non-state-owned enterprises to invest in shares, participate in } \\
\text { public technology platforms and hydrology. }\end{array}$ \\
$\begin{array}{ll}\text { National reserves of strategic materials such as grain, oil and } \\
\text { natural gas. }\end{array}$ & \begin{tabular}{l} 
Maintain state-owned or holding. \\
\hline
\end{tabular}
\end{tabular}

\section{Difficulties in the Implementation of the Reform of State-Owned Enterprises}

The reform of state-owned enterprise classification is an effective solution to the problem of efficiency and ownership, but there are still some difficult problems to be solved in the process of implementation.

\subsection{The Contradiction between "Diversified and Multi-Functional" State-Owned Enterprises and Classified Supervision}

In the implementation of the classification of state-owned enterprises, the provinces of China have basically made a more detailed division on the basis of the "three-point method" of the central government. We can see that the positioning of commercial state-owned enterprises and public welfare state-owned enterprises is relatively clear, but functional state-owned enterprises may have to assume the dual functions of social benefits and economic benefits in reality. This kind of multi-functional state-owned enterprises will produce between the market and public logic. contradiction. If the regulatory assessment shifts to efficiency, there may be a shortage of public goods and public services; on the contrary, if the regulatory assessment shifts to social benefits, there will be inefficiencies. So there is a paradox, the supervision of state-owned enterprises is to improve efficiency, but because of the existence of multi-functional state-owned enterprises, it may reduce efficiency.

\subsection{It Is Difficult to Classify Reforms with for-Profit Natural Monopoly and Resource Scarce State-Owned Enterprises}

Generally speaking, public welfare enterprises are non-profit and there is no public domain in the market competition, and profitable enterprises need to be in a fully competitive market environment to improve efficiency. The classification of state-owned enterprises must be clearly defined. However, the function and positioning of for-profit state-owned enterprises in natural monopoly and resource scarcity in classification reform are difficult to define. First of all, on the one hand, for-profit enterprises cannot be classified as public welfare enterprises, but on the other hand, "natural" has strong market power and it is difficult to fully participate in competition to enjoy monopoly profits. It is impossible to actively participate in market competition and improve efficiency through property rights and internal governance reforms, just like ordinary 
commercial enterprises. It cannot provide public goods like public welfare enterprises, and its economic benefits are greater than the social and political benefits of national strategic level. The type of state-owned enterprises will become a major difficulty in how classification reforms are implemented.

\subsection{Mixed Change of Cross-Shareholding and State-Owned Capital Preservation and Appreciation is Still a} Major Difficulty

In the practice of local state-owned enterprise classification reform, mixed ownership reform is the $\mathrm{N}$ in the " $1+\mathrm{N}$ " policy of state-owned enterprise classification reform. The classification of state-owned enterprises is the basis of mixed reform, and the mixed reform is a concrete means to promote the reform of state-owned enterprises. The two complement each other. In the operation, the reform of state-owned enterprises can not only open the "gate" of state-owned enterprise property rights, but also allow private enterprises and other non-private enterprises to participate in shareholding control. It can also invest in other enterprises through the state-owned capital operation platform. Cross-shareholding will become a normal state. However, mixed reform must achieve efficient investment of state-owned capital and ensure the preservation and appreciation of state-owned capital. When state-owned capital invests in private capital or other state-owned capital, it may impose higher requirements on corporate profitability. This situation will give equity holding companies Bring greater profit pressure.

\subsection{Structural Conflicts between "Rights" and "Human Rights"}

The relationship between state-owned enterprises and state-owned assets supervision departments belongs to investors and managers. One of the objectives of this state-owned enterprise classification reform is to weaken the adverse effects of improper supervision of state-owned assets supervision departments on state-owned enterprises and gradually manage the "rights of management" of assets. Decentralized to state-owned enterprises. The board of directors of commercial state-owned enterprises can adopt the method of market selection and evaluation for the managerial level, but when the commercial state-owned enterprises realize the diversification of equity, the chairman (party secretary) is still appointed and removed by the state-owned assets supervision department, which is elected by the board of directors. The resulting modern corporate governance system is contrary to each other. If the chairman of the board makes a major problem in the business decision-making or fails to meet the employer's criteria and cannot use the internal governance mechanism to eliminate it, it will be constrained by the business management. This kind of "decentralization" and "human rights" are not A situation of complete decentralization will inevitably lead to conflict.

\section{Policy Recommendations to Promote the Effective Implementation of the Classification Reform of State-Owned Enterprises}

5.1 Supervision Needs to Develop An Assessment Index of "Combination of Movement And Static, and Clear Hierarchy"

The classified state-owned enterprises, especially the fully competitive state-owned enterprises, will face a more complicated market, economic and social environment in the actual operation process. The stable evaluation indicators are not conducive to the formation of an effective incentive compatibility mechanism, so the indicator setting should include Both static and dynamic indicators can reflect both the regular business situation and the ability to adapt to changes in the external environment. When the indicators of different types of state-owned enterprises are set, the degree of "moving and static" is not consistent, and the principle of "one enterprise, one test" should be adhered to. The assessment indicators of public-sector state-owned enterprises should be based on the quantity and quality of public goods, and the index setting should be relatively stable and single; while the fully competitive state-owned enterprises should still highlight the financial indicators consistent with market dynamics, and the method of balanced scoring can be used. The assessment indicators will be classified into different categories; functional SOEs should achieve separation and assessment of market business and strategic business segments.

5.2 For "Diversified, Multi-Functional" State-Owned Enterprises, They should Use the Means of Mergers and Acquisitions and Restructuring and Divesting Assets to Highlight the Main Business

The unclear positioning of "diversified, multi-functional" state-owned enterprises will create obstacles for future regulation. In order to facilitate supervision and improve the efficiency of the use of enterprise resources, it is necessary to centrally dispose of business and assets. In the reform, the "diversified and multi-functional" state-owned enterprises can "combine and diversify" the business assets, and reorganize and integrate the assets with overlapping functions to achieve economies of scale. Assets that do not achieve the established economic benefits or social benefits can be divested. In this way, other state-owned enterprises with operational capabilities 
and experience can highlight their own comparative advantages and achieve asset efficiency improvement.

5.3 Natural Monopoly State-Owned Enterprises and Resource-Scarce State-Owned Enterprises Can Set Separate Classifications for Regulatory Assessment

Due to the particularity of natural monopoly and resource-poor state-owned enterprises, these two types of enterprises are different from public welfare and fully competitive state-owned enterprises. Although they can be attributed to functional state-owned enterprises, it is difficult to improve operational efficiency through competition. These two state-owned enterprises belong to the "reasonable" monopoly enterprises. They should be separately classified to conduct regulatory assessments, and they can mainly conduct supervision and assessment on profit and cost control. Natural monopoly state-owned enterprises should ensure that product pricing is above the average cost to ensure that profits are within a reasonable range, that the operation maintains breakeven and appropriate expansion of reproduction, and excess profits need to be turned over to the central government; the operating and mining cost indicators of resource-scarce state-owned enterprises are based on 5The long-term average of 10 years sets a reasonable range that can be up and down, and rewards and punishments according to the actual situation of cost control.

\subsection{Equity "Diversified” State-Owned Enterprises should Consider the Owner's Equity More}

The reform of mixed ownership is an important measure to promote the reform of state-owned enterprises from the perspective of property rights. The original intention of the reform of mixed ownership is to introduce market components into the property rights structure of state-owned enterprises, so as to improve internal governance and improve the efficiency of capital operation. The most far-reaching effects of mixed reforms are commercial state-owned enterprises, especially competitive state-owned enterprises. In order to give full play to the role of mixed reforms and increase the enthusiasm of private capital participation, the mixed reform should coordinate the relationship between the value-added of state-owned capital and the rights of private capital. First of all, we must adhere to the principle of equal rights with the same stocks. For private equity with a low share of equity, it is necessary to appropriately increase the number of seats on the board of directors to enhance the right to speak. Second, form a reasonable shareholding structure. Competitive state-owned enterprises can relax the proportion of private capital, but it is necessary to prevent the excessive proportion of single private capital. Third, establish a capital investment fault tolerance mechanism and a long-term inspection mechanism. The investment in mixed reform is two-way, whether it is private capital entering state-owned enterprises or state-owned enterprises holding private enterprises.

\section{References}

China Macroeconomic Analysis and Forecasting Group. (2017). New Reforming Ideas Of New State-Owned Enterprises In The New Era-The Logic, Path and Implementation of the Classification and Reform of State-owned Enterprise. Economic Theory and Business Management, (5).

Commonness and Differences (2012). Analysis Report on Local SOE Classification Reform. State capital report.

Jin, B. (2010). Thinking on Repositioning and Reform of State owned Enterprises. China Market, (9). https//doi.org/10.3969/j.issn.1005-6432.2010.37.008

Xu, D. D., \& Zeng, Z. B. (2016). Current Situation and Prospects of the Realization Path of State-owned Enterprises Classification Reform. Finance and Accounting Monthly, (22).

\section{Note}

Note 1. China Macroeconomic Analysis and Forecasting Group. NEW REFORMING IDEAS OF NEW STATE-OWNED ENTERPRISES IN THE NEW ERA-The Logic, Path and Implementation of the Classification and Reform of State-owned Enterprises [J]. Economic Theory and Business Management. 2017(5)

\section{Copyrights}

Copyright for this article is retained by the author(s), with first publication rights granted to the journal.

This is an open-access article distributed under the terms and conditions of the Creative Commons Attribution license (http://creativecommons.org/licenses/by/4.0/). 